\title{
Mineral Resources of the Sabinoso Wilderness Study Area, San Miguel County, New Mexico
}
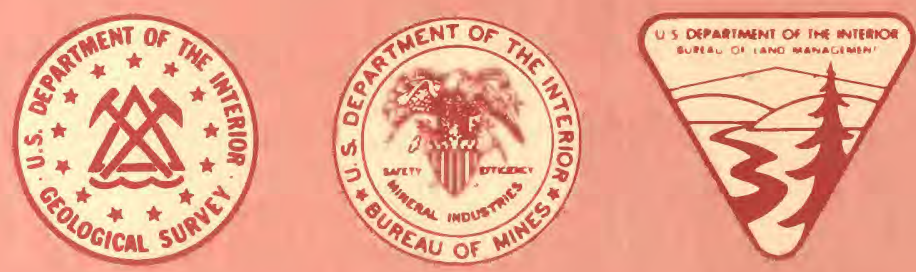

\section{U.S. GEOLOGICAL SURVEY BULLETIN 1733-A}

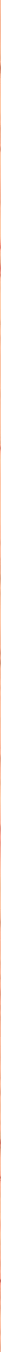



Chapter A
Mineral Resources of the
Sabinoso Wilderness Study Area, San Miguel County, New Mexico

By ANNE M. LEIBOLD, RICHARD W. SALTUS, V.J.S. GRAUCH, and DAVID A. LINDSEY

U.S. Geological Survey

CARL L. ALMQUIST

U.S. Bureau of Mines

U.S. GEOLOGICAL SURVEY BULLETIN 1733

MINERAL RESOURCES OF WILDERNESS STUDY AREASNORTHERN NEW MEXICO 


\title{
DEPARTMENT OF THE INTERIOR DONALD PAUL HODEL, Secretary
}

\author{
U.S. GEOLOGICAL SURVEY \\ Dallas L. Peck, Director
}

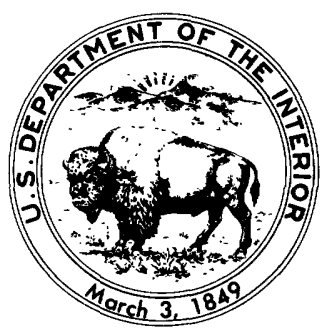

For sale by the

Books and Open-File Reports Section

U.S. Geological Survey

Federal Center

Box 25425

Denver, CO 80225

Library of Congress Cataloging-in-Publication Data

Mineral resources of the Sabinoso Wilderness Study Area, San Miguel County, New Mexico.

(U.S. Geological Survey bulletin ; 1733)(Mineral resources of wilderness study areas-northern New Mexico; ch. A)

Bibliography: $p$.

1. Mines and mineral resources-New Mexico-Sabinoso Wilderness.

2. Geology-New Mexico-Sabinoso Wilderness.. I. Leibold, Anne M.

II. Series: Geological Survey bulletin ; 1733. III. Series: Mineral resources of wilderness study areas-northern New Mexico ; ch. A. QE75.B9 no. 1733-A $557.3 \mathrm{~s}$ [TN24.N6]

[553'.09789'55] 


\section{STUDIES RELATED TO WILDERNESS}

\section{Bureau of Land Management Wilderness Study Areas}

The Federal Land Policy and Management Act (Public Law 94-579, October 21, 1976) requires the U.S. Geological Survey and the U.S. Bureau of Mines to conduct mineral surveys on certain areas to determine the mineral values, if any, that may be present. Results must be made available to the public and be submitted to the President and the Congress. This report presents the results of a mineral survey of the Sabinoso Wilderness Study Area (NM-010-055), San Miguel County, New Mexico. 


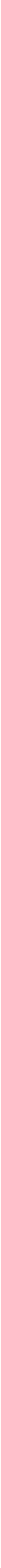




\title{
CONTENTS
}

\author{
Summary A1
}

Introduction $\mathbf{A 1}$

Investigations by the U.S. Bureau of Mines A3

Investigations by the U.S. Geological Survey $\mathbf{A 3}$

Appraisal of identified resources $\mathbf{A 3}$

Mining and mineral-exploration activity

Oil and gas $\mathbf{A 3}$

Uranium A3

Appraisal of sites examined A6

Assessment of potential for undiscovered resources A6

Geology A6

Geophysics A7

Gravity data A7

Aeromagnetic data A7

Interpretation of gravity and magnetic data $\mathbf{A 7}$

Radiometric data A10

Mineral and energy resources A11

References cited A11

Appendix $\mathbf{A 1 3}$

\section{PLATE}

[Plate is in pocket]

1. Map showing mineral resource potential, geology, and sample localities of the Sabinoso Wilderness Study Area

\section{FIGURES}

1. Summary map showing mineral resource potential and location of the Sabinoso Wilderness Study Area A2

2. Location map for the Sabinoso Wilderness Study Area $\mathbf{A 3}$

3. Isostatic residual gravity map of the Sabinoso Wilderness Study Area and vicinity $\mathbf{A 8}$

4. Aeromagnetic map of the Sabinoso Wilderness Study Area and vicinity A9

5. Pseudogravity map of the Sabinoso Wilderness Study Area and vicinity A10

\section{TABLE}

1. Data for U.S. Bureau of Mines chip samples from the Sabinoso Wilderness Study Area and vicinity A4 


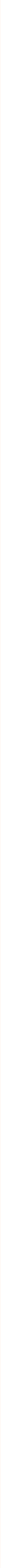




\title{
Mineral Resources of the Sabinoso Wilderness Study Area, San Miguel County, New Mexico
}

\author{
By Anne M. Leibold, Richard W. Saltus, V.J.S. Grauch, and David A. Lindsey \\ U.S. Geological Survey
}

Carl L. Almquist

U.S. Bureau of Mines

\section{SUMMARY}

In 1985 and 1986 the U.S. Geological Survey and the U.S. Bureau of Mines conducted studies to appraise the identified mineral resources and assess the mineral resource potential of the Sabinoso (NM-010-055) Wilderness Study Area. The investigation included a review of previous geological studies, geological mapping from aerial photographs and field examination, and field studies of mines, prospects, and mineralized areas in and near the wilderness study area.

The Sabinoso Wilderness Study Area includes 15,760 acres of mesa and canyon country between the communities of Trujillo and Sabinoso, San Miguel County, New Mexico (fig. 1). Flat-lying and gently dipping Mesozoic sedimentary rocks are exposed in the study area. Unimproved roads from New Mexico Highway 65 extend to the perimeter; however, access to most of the study area is limited to foot and horseback.

No identified mineral resources were found in the study area. Uranium occurrences inside the study area are associated with accumulations of carbonaceous material in the middle member of the Chinle Formation, but these deposits are small and low grade, and do not constitute a uranium resource. There are no known leasable, locatable, or salable mineral resources in the wilderness study area.

Geological and geophysical studies indicate a moderate mineral resource potential for undiscovered uranium in the middle member of the Chinle Formation in the study area. The mineral potential is low for undiscovered resources of all metals other than uranium and for oil and gas in the study area.

\section{INTRODUCTION}

The Sabinoso Wilderness Study Area consists of 15,760 acres of mesa and canyon country between the communities of Trujillo and Sabinoso, San Miguel County, New Mexico (fig. 2). Canon Largo, which roughly coincides with the northwestern boundary of the study area, enters the Canadian River at Sabinoso. Flatlying to very gently dipping Mesozoic (see Appendix for geologic time chart) sedimentary rocks which cover the area are carved into narrow plateaus and mesas, surrounded by steep, rugged canyons. Units which crop out in the study area include the Santa Rosa, Chinle, Entrada, Morrison, and Mesa Rica Formations. Elevations in the study area range from about 4,500 to $6,000 \mathrm{ft}$ (feet). Most of the study area is surrounded by privately owned land. Jeep roads exist in the study area, but visitors must secure permission from the U.S. Bureau of Land Management to drive on them. Unimproved roads from New Mexico Highway 65 lead to the perimeter; however, public access into most of the study area is limited to foot and horseback.

This report presents an evaluation of the mineral endowment (identified resources and mineral resource potential) of the study area and is the product of several separate studies by the USBM (U.S. Bureau of Mines) and the USGS (U.S. Geological Survey). Identified resources are classified according to the system of the U.S. Bureau of Mines and U.S. Geological Survey (1980), which is shown in the Appendix of this report. Identified resources are studied by the USBM. Mineral resource po- 


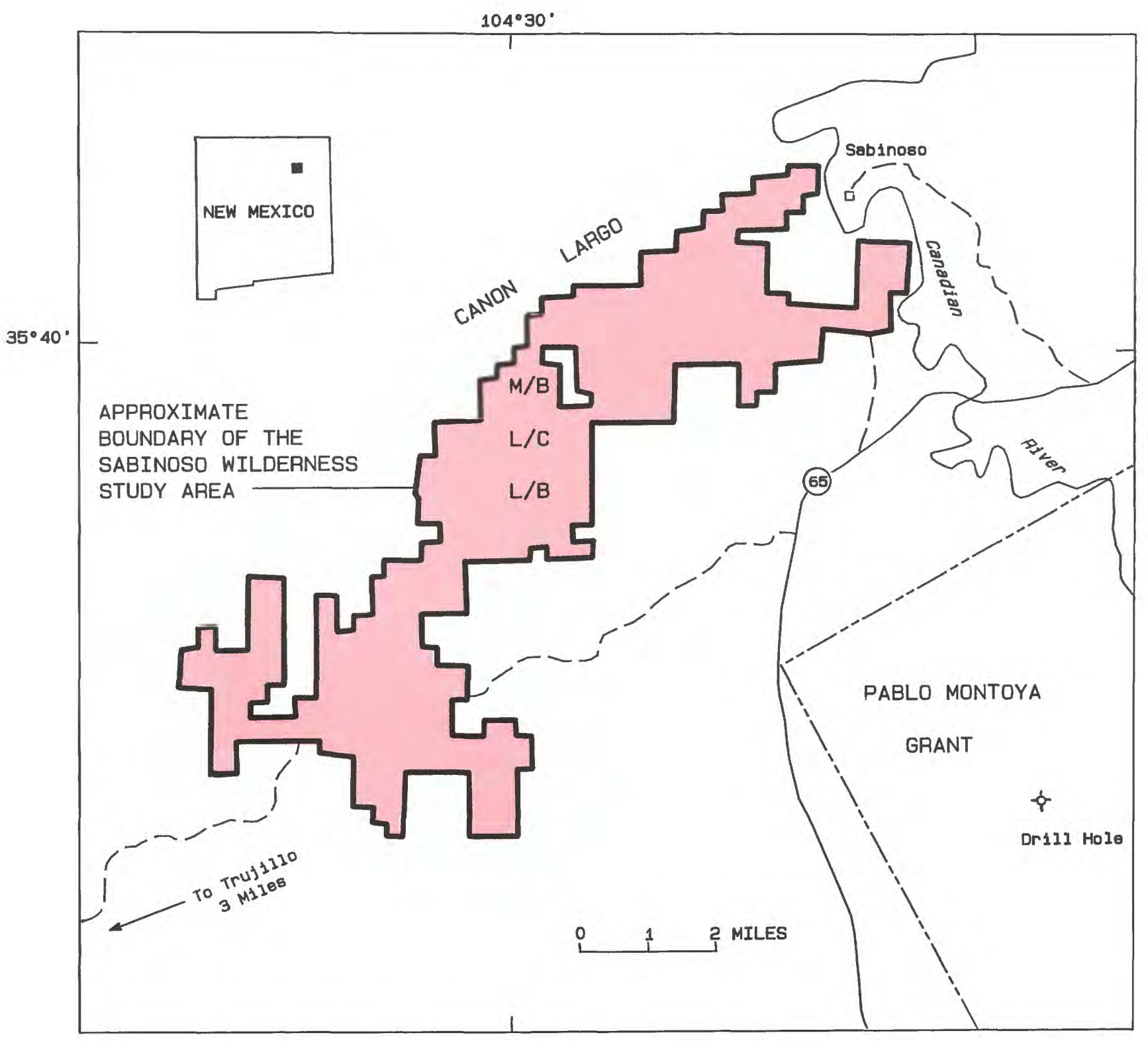

\section{EXPLANATION}

M/B Geologic terrane having moderate mineral resource potential for uranium in the middle member of the Chinle Formation, with certainty level B

L/B Geologic terrane having low mineral resource potential for uranium in the Morrison Formation and low energy resource potential for oil and gas, with certainty level B

L/C Geologic terrane having low mineral resource potential for all metals other than uranium with certainty level C

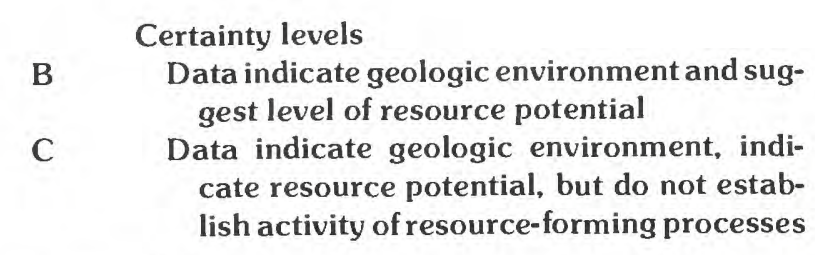

- Unpaved road

Figure 1. Summary map showing mineral resource potential of the Sabinoso Wilderness Study Area, San Miguel County, New Mexico. 


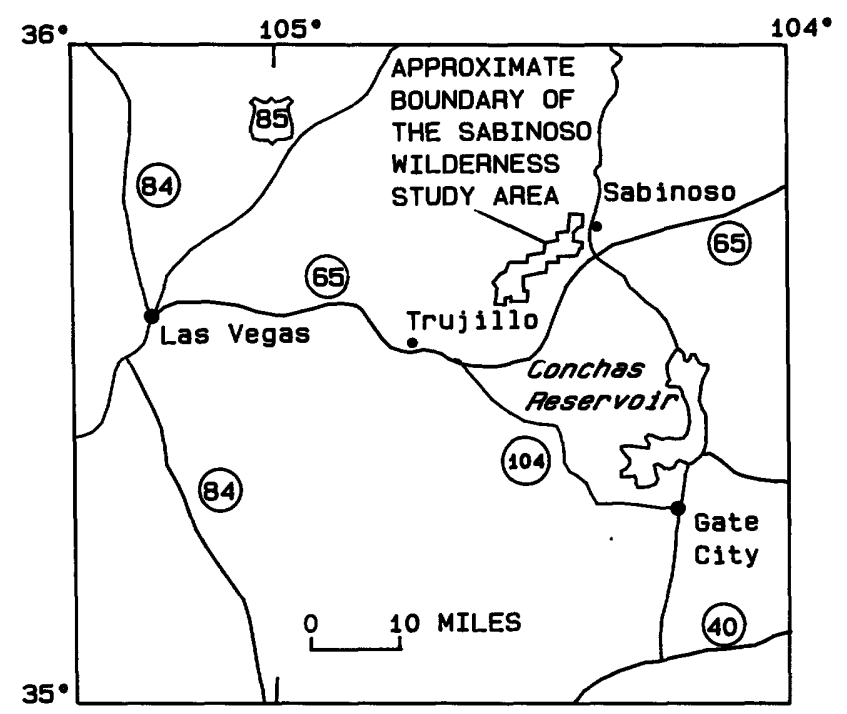

Figure 2. Location map for the Sabinoso Wilderness Study Area, New Mexico.

tential is the likelihood of occurrence of undiscovered metals and nonmetals, industrial rocks and minerals, and of undiscovered energy sources (coal, oil, gas, oil shale, and geothermal sources). It is classified according to the system of Goudarzi (1984) and is shown in the Appendix. Undiscovered resources are studied by the USGS.

\section{Investigations by the U.S. Bureau of Mines}

The USBM surveyed and studied mines, prospects, and mineralized areas to appraise reserves and identified subeconomic resources. The results of its study were given in detail in Almquist (1986). The USBM investigation included reviews of published literature, mining-claim records, and land-status records, after which two USBM geologists conducted a five-day field examination of mines, prospects, and mineralized areas in and near the wilderness study area. A helicopter was used for access and reconnaissance. Radioactivity in selected areas was measured with a scintillometer. Thirty-eight chip samples were collected and analyzed by inductively coupled plasma-atomic emission spectroscopy for copper, vanadium, and molybdenum; by fluorometric methods for uranium; and by fire assay for gold and silver (table 1). Fourteen of the samples were also analyzed by optical emission spectroscopy for 40 elements. Results of these analyses are available for public inspection at the Branch of Mineral Land Assessment, Intermountain Field Operations Center, Building 20, Denver Federal Center, Denver, CO 80225.

\section{Investigations by the U.S. Geological Survey}

The USGS conducted field and office investigations to obtain necessary information to assess the potential for undiscovered mineral resources in the Sabinoso Wilderness Study Area. This investigation included a review of previous geological work, new geological mapping from aerial photographs and field studies, gravity, aeromagnetic, and aerial gamma-ray studies, and field examination of similar mineralized terranes nearby. The gravity study included construction of an isostatic residual gravity map from 64 ground gravity stations in and near the study area. Fifty-one stations were established by the USGS in May 1986, and data from 13 stations were previously assembled and edited for regional gravity maps of New Mexico (Cordell and others, 1982). An aeromagnetic map was constructed from data collected in December 1985 by EG\&G Geometrics under contract to the USGS. As part of a state mapping project, the aerial gamma-ray data for New Mexico were compiled and processed to produce a series of 1:1,000,000 maps. These maps include the composite-color maps described by Duval (1983).

Acknowledgments.-S. J. Soulliere assisted in field work. We thank Darrell Musick and I. D. Randall of the U.S. Bureau of Land Management for assistance in the field area.

\section{APPRAISAL OF IDENTIFIED RESOURCES}

\section{By Carl L. Almquist \\ U.S. Bureau of Mines}

\section{Mining and Mineral-Exploration Activity}

\section{Oil and Gas}

The nearest drill holes having recorded hydrocarbon shows are between 7 and $12 \mathrm{mi}$ (miles) east of the Sabinoso Wilderness Study Area. About 1,600 acres in the study area were under lease for oil and gas as of January 1986 (pl. 1). Current oil and gas leasing information is available for public inspection at the U.S. Bureau of Land Management, New Mexico State Office, Santa Fe, N. Mex.

\section{Uranium}

Most of the known uranium occurrences in eastern New Mexico are near the base of the middle member of the Chinle Formation. Many of these occurrences are near Sabinoso (Finch, 1972), where uranium was discovered in 1952 (Wanek, 1962). An airborne radiometric sur- 
Table 1. Data for U.S. Bureau of Mines chip samples from the Sabinoso Wilderness Study Area and vicinity, New Mexico

[Tr., trace; -, not detected; <, less than; ppm, parts per million; oz, ounce. Analyses by assay. Detection limits: uranium, 0.5 ppm; vanadium, $5 \mathrm{ppm}$; copper, $6 \mathrm{ppm}$; molybdenum, $5 \mathrm{ppm}$; silver, $0.1 \mathrm{oz} / \mathrm{short}$ ton; gold, $0.005 \mathrm{oz} /$ short ton. Samples are from middle member of Chinle Formation unless otherwise noted. Sample localities shown on pl. 1]

\begin{tabular}{|c|c|c|c|c|c|c|c|c|}
\hline \multicolumn{2}{|c|}{ Sample } & \multicolumn{4}{|c|}{ In $\mathrm{ppm}$} & & \multirow[b]{2}{*}{ Remarks } \\
\hline No. & $\begin{array}{l}\text { Length } \\
(\mathrm{f} t)\end{array}$ & $\mathrm{U}$ & $\mathrm{V}$ & $\mathrm{Cu}$ & Mo & $\overline{\mathrm{Ag}}$ & $\frac{\operatorname{ton}}{\mathrm{Au}}$ & \\
\hline 1 & 1.7 & 528 & $0.60 *$ & 520 & 370 & 0.5 & -- & $\begin{array}{l}\text { Former Hunt oil Co. mining claims; } 15-\mathrm{ft}-\text { long } \\
\text { adit; } 20-i n \text {. -thick lens of carbonaceous silty } \\
\text { shale interbedded with sandstone; uranium } \\
\text { mineral ianthinite identified by X-ray dif- } \\
\text { fraction; minor malachite. }\end{array}$ \\
\hline 2 & 1.5 & 116 & $.17 *$ & 450 & 22 & .1 & $\operatorname{Tr}$. & Do. \\
\hline 3 & 2.9 & 232 & $.23 *$ & 290 & 82 & -- & -- & Do. \\
\hline 4 & 3.0 & 19 & 130 & 200 & 380 & .2 & $\operatorname{Tr}$. & $\begin{array}{l}\text { Pocket of carbonaceous material, including an } \\
8 \text {-ft-long } \log \text {, in sandstone outcrop; abundant } \\
\text { limonite. }\end{array}$ \\
\hline 5 & 6.5 & 21 & 55 & 61 & 20 & .1 & $\operatorname{Tr}$. & $\begin{array}{l}\text { Minor carbonaceous material in interbedded sand- } \\
\text { stone, siltstone, and limestone-pebble } \\
\text { conglomerate. }\end{array}$ \\
\hline 6 & 3.0 & 13 & 65 & 12 & 16 & -- & Tr. & $\begin{array}{l}\text { Minor carbonaceous material in interbedded silt- } \\
\text { stone and limestone-pebble conglomerate. }\end{array}$ \\
\hline 7 & 1.0 & 21 & 71 & 76 & 730 & .2 & -- & $\begin{array}{l}\text { Pocket of carbonaceous material in lenticular } \\
\text { sandstone. }\end{array}$ \\
\hline 8 & 2.0 & 2.5 & 110 & 360 & 16 & -- & -- & $\begin{array}{l}\text { Minor carbonaceous material in interbedded } \\
\text { sandstone, siltstone, and limestone-pebble } \\
\text { conglomerate. }\end{array}$ \\
\hline 9 & 2.0 & 3.3 & 78 & 19 & 13 & -- & -- & Do. \\
\hline 10 & 3.3 & 2.0 & 190 & 45 & 15 & -- & -- & Do. \\
\hline 11 & 1.8 & 10 & 100 & 16 & 24 & -- & Tr. & $\begin{array}{l}\text { Vicinity of U.S. Atomic Energy Commission } \\
\text { radiometric anomaly; minor carbonaceous } \\
\text { material in lenticular siltstone. }\end{array}$ \\
\hline 12 & 2.5 & 3.4 & 76 & 160 & 18 & -- & Tr. & $\begin{array}{l}\text { Former Running H claims; minor carbonaceous } \\
\text { material in interbedded limestone-pebble } \\
\text { conglomerate and silty sandstone. }\end{array}$ \\
\hline 13 & 3.5 & 2.5 & 60 & 16 & 14 & -- & -- & $\begin{array}{l}\text { Former Mickie V claims; minor carbonaceous } \\
\text { material in interbedded sandstone and siltstone. }\end{array}$ \\
\hline 14 & 2.0 & 53 & $0.10 *$ & 25 & 29 & -- & -- & $\begin{array}{l}\text { Windy No. } 9 \text { mine; } 81-\mathrm{ft}-1 \text { ong adit; lenses as } \\
\text { much as } 1 \mathrm{ft} \text { thick of carbonaceous material in } \\
\text { interbedded sandstone, siltstone, clay, and } \\
\text { limestone-pebble conglomerate. }\end{array}$ \\
\hline 15 & 2.0 & 22 & $.12^{\star}$ & 120 & 14 & .1 & -- & Do. \\
\hline 16 & 5.0 & 48 & 850 & 74 & 46 & -- & - & Do. \\
\hline 17 & 2.5 & 135 & 110 & 28 & 660 & .6 & -- & Do. \\
\hline 18 & 3.0 & 447 & 820 & 28 & 520 & .6 & -- & Do. \\
\hline 19 & 3.3 & 5.4 & 140 & 310 & 20 & -- & -- & $\begin{array}{l}\text { Bish No. } 2 \text { mine; not safely accessible; sampled } \\
\text { outcrop at portal; minor carbonaceous material } \\
\text { in interbedded sandstone and limestone-pebble } \\
\text { conglomerate. }\end{array}$ \\
\hline 20 & 2.6 & 67 & 84 & 67 & 500 & .1 & -- & $\begin{array}{l}\text { Former Sabinoso Uranium Co. mining claims; } \\
38 \text {-ft-long adit; stringers of carbonaceous } \\
\text { material in interbedded limestone-pebble } \\
\text { conglomerate, sandstone, and siltstone; minor } \\
\text { malachite. }\end{array}$ \\
\hline
\end{tabular}


Table 1. Data for U.S. Bureau of Mines chip samples from the Sabinoso Wilderness Study Area and vicinity, New Mexico-Continued

\begin{tabular}{|c|c|c|c|c|c|c|c|c|}
\hline \multicolumn{2}{|c|}{ Sample } & \multicolumn{4}{|c|}{ In $\mathrm{ppm}$} & \multicolumn{2}{|c|}{$\begin{array}{c}\text { In oz/short } \\
\text { ton }\end{array}$} & \multirow{2}{*}{ Remarks } \\
\hline No. & $\begin{array}{l}\text { Length } \\
(\mathrm{ft})\end{array}$ & $\overline{\mathrm{U}}$ & $\mathrm{V}$ & $\mathrm{Cu}$ & Mo & $\overline{\mathrm{Ag}}$ & $\mathrm{Au}$ & \\
\hline 21 & 1.6 & 124 & 260 & 29 & 62 & -- & Tr. & $\begin{array}{l}\text { Former Sabinoso Uranium Co. mining claims; } \\
\text { 38-ft-long adit; stringers of carbonaceous } \\
\text { material in interbedded limestone-pebble } \\
\text { conglomerate, sandstone, and siltstone; minor } \\
\text { malachite. }\end{array}$ \\
\hline 22 & 3.7 & 23 & 66 & 99 & 140 & 0.3 & -- & $\begin{array}{l}\text { Cip Lujan, south prospect; minor carbonaceous } \\
\text { material in pebble conglomerate. }\end{array}$ \\
\hline 23 & 3.0 & 61 & 80 & 69 & 850 & -- & -- & $\begin{array}{l}\text { Cip Lujan, north prospect; pocket of carbonaceous } \\
\text { material in siltstone. }\end{array}$ \\
\hline 24 & 2.8 & 3.3 & 110 & 26 & 15 & - & -- & $\begin{array}{l}\text { Across canyon from Windy No. } 9 \text { mine at same } \\
\text { stratigraphic level; minor carbonaceous material } \\
\text { in interbedded limestone-pebble conglomerate } \\
\text { and sandstone. }\end{array}$ \\
\hline 25 & 2.0 & 2.7 & 200 & 13 & 17 & -- & -- & $\begin{array}{l}\text { Radioactive zone in interbedded limestone-pebble } \\
\text { conglomerate and sandstone. }\end{array}$ \\
\hline 26 & 4.8 & 1.2 & 61 & 16 & 14 & -- & -- & $\begin{array}{l}\text { Radioactive zone in interbedded shale } \\
\text { and siltstone. }\end{array}$ \\
\hline 27 & 3.2 & 2.0 & 130 & 23 & 19 & -- & -- & $\begin{array}{l}\text { Radioactive zone in interbedded shale, sandstone, } \\
\text { and mudstone. }\end{array}$ \\
\hline 28 & 3.5 & 4.1 & 82 & 22 & 58 & -- & -- & $\begin{array}{l}\text { Small pocket of carbonaceous material and limonite } \\
\text { in sandstone outcrop. }\end{array}$ \\
\hline 29 & 3.0 & 6.1 & 62 & 13 & 44 & .1 & Tr. & $\begin{array}{l}\text { Radioactive zone in interbedded limestone-pebble } \\
\text { conglomerate and sandstone outcrop. }\end{array}$ \\
\hline 30 & 2.0 & 9.8 & 110 & 49 & 140 & .1 & -- & $\begin{array}{l}\text { Carbonaceous material in limestone-pebble } \\
\text { conglomerate outcrop; local rancher reported } \\
\text { uranium occurrences in this area. }\end{array}$ \\
\hline 31 & 3.7 & 5.1 & 68 & 6.1 & 16 & .1 & -- & $\begin{array}{l}\text { Radioactive zone in carbonaceous sandstone } \\
\text { outcrop. }\end{array}$ \\
\hline 32 & 4.0 & 5.3 & 200 & 10 & 29 & -- & Tr. & $\begin{array}{l}\text { Former Gloria No. } 1 \text { mining claim; minor } \\
\text { carbonaceous material in interbedded sandstone, } \\
\text { siltstone, and limestone-pebble conglomerate } \\
\text { outcrop. }\end{array}$ \\
\hline 33 & 4.0 & - & 17 & $<6$ & 7.2 & -- & -- & $\begin{array}{l}\text { Morrison Formation sandstone outcrop; sampled for } \\
\text { reference. }\end{array}$ \\
\hline 34 & 3.7 & 2.7 & 40 & $<6$ & 9.5 & -- & -- & Do. \\
\hline 35 & 5.0 & -- & 15 & $<6$ & 14 & -- & - & Do. \\
\hline 36 & 3.3 & 1.5 & 25 & $<6$ & 17 & -- & -- & $\begin{array}{l}\text { Former Mars mining claims; examined by U.S. Bureau } \\
\text { of Mines in late } 1950^{-5} \text { (Mineral Property File } \\
75.37 \text { ); no workings found. }\end{array}$ \\
\hline 37 & 2.0 & .69 & 16 & $<6$ & 13 & - & -- & $\begin{array}{l}\text { Morrison Formation sandstone outcrop; sampled for } \\
\text { reference. }\end{array}$ \\
\hline 38 & 4.0 & 10 & 32 & 23 & 18 & -- & Tr. & $\begin{array}{l}\text { Radioactive zone in Morrison Formation sandstone } \\
\text { outcrop. }\end{array}$ \\
\hline
\end{tabular}

*Values are in percent. 
vey flown in 1953 for the U.S. Atomic Energy Commission identified two anomalies in the wilderness study area (pl. 1) (U.S. Atomic Energy Commission, 1966). The only subsequent minerals-related activities in the study area, other than oil and gas leasing, were prospecting, exploration, and locating mining claims for uranium. As of February 1986, all of the mining claims in the study area had been abandoned.

In 1956, two mines near the wilderness study area, the Bish No. 2 and the Windy No. 9 (pl. 1), produced single test shipments of uraniferous material which were sent to Grants, N. Mex., for processing (McLemore and Menzie, 1983). Thirty tons from the Bish No. 2 yielded $62 \mathrm{lb}$ of $\mathrm{U}_{3} \mathrm{O}_{8}$ and $27 \mathrm{lb}$ of $\mathrm{V}_{2} \mathrm{O}_{5}$. Nineteen tons from the Windy No. 9 yielded $19 \mathrm{lb}$ (pounds) of $\mathrm{U}_{3} \mathrm{O}_{8}$ and $147 \mathrm{lb}$ of $\mathrm{V}_{2} \mathrm{O}_{5}$ (McLemore and Menzie, 1983). Twentyone holes drilled to an average depth of $100 \mathrm{ft}$ at the Windy No. 9 failed to locate significant additional uranium (Allison, 1956). No further production occurred at either mine.

\section{Appraisal of Sites Examined}

There are no identified resources in the study area. Results of the USBM study confirmed findings of investigations by the U.S. Atomic Energy Commission (195356), Finch (1972), and McLemore and Menzie (1983): known uranium occurrences in the Sabinoso Wilderness Study Area and vicinity are small, scattered, and lowgrade (less than 0.10 percent $\mathrm{U}_{3} \mathrm{O}_{8}$ ). Data for samples collected by the USBM are summarized on table 1 .

With one exception (sample 38, table 1), uranium occurrences examined during this study are in carbonaceous rocks near the base of the middle member of the Chinle Formation. In exposures of this member throughout the wilderness study area, radioactive zones are about $2 \mathrm{ft}$ thick and extend along strike for 5-30 ft. Within these zones, uranium is associated with scattered accumulations of carbonized organic material, generally between 1 in. (inch) and $1 \mathrm{ft}$ thick, in lenses of silty clay, sandstone, and limestone-pebble conglomerate. The middle member of the Chinle Formation was probably deposited in a complex braided-stream environment (Wanek, 1962), which would account for the scattered lenslike nature of uranium host material.

The highest uranium value detected in USBM samples was $528 \mathrm{ppm}$ (parts per million) or about 0.05 percent (sample 1, table 1). By comparison, uranium ore which is currently (1987) of commercial-grade averages at least 0.30 percent $\mathrm{U}_{3} \mathrm{O}_{8}$ (George Granbouche, geologist, U.S. Department of Energy, Grand Junction, Colo., oral commun., 1986), which is equivalent to 0.26 percent uranium.

The only known mineral commodity of interest in the Sabinoso Wilderness Study Area is uranium. Scattered small low-grade occurrences are present, but they do not constitute a mineral resource. There are no other known leasable, locatable, or salable mineral or energy resources in the Sabinoso Wilderness Study Area.

\section{ASSESSMENT OF POTENTIAL FOR UNDISCOVERED RESOURCES}

\author{
By Anne M. Leibold, Richard W. Saltus, \\ V.J.S. Grauch, and David A. Lindsey \\ U.S. Geological Survey
}

\section{Geology}

The following description of geologic setting and rock units was modified from Wanek (1962) and McLemore and Menzie (1983).

The Sabinoso Wilderness Study Area lies on the eastern flank of the southwest-trending Sierra Grande arch which forms a broad uplift in northeastern New Mexico. Triassic, Jurassic, and Cretaceous sedimentary rocks, which are flat lying or dip very gently to the southeast, are exposed in the study area (pl. 1). Geophysical and well-log data from the area indicate that these rocks are underlain by a sequence of Permian and Pennsylvanian sedimentary rocks, as much as $2,500 \mathrm{ft}$ thick, and Precambrian crystalline rocks (Wanek, 1962; U.S. Department of the Interior, Bureau of Land Management, 1985).

The Santa Rosa Formation of Late Triassic age is exposed in the northeastern part of the study area, south of Sabinoso. Yellowish-gray to buff lenticular sandstone beds, 6-10 ft thick, are intercalated with thick beds of reddish-brown shale and siltstone making up a total thickness of as much as $300 \mathrm{ft}$. The sandstone is massive, crossbedded, medium grained, and calcareous, and was probably deposited in streams on an ancient alluvial plain. The upper part of the Santa Rosa Formation intertongues with the overlying Chinle Formation.

The Triassic Chinle Formation is composed of three unnamed members: a lower shale, a middle sandstone, and an upper shale. The lower slope-forming shale, as much as $170 \mathrm{ft}$ thick, is composed of interbedded grayishred and greenish-gray shales and siltstones, thin beds of pale-yellowish-gray to brown sandstone, and gray limestone-pebble conglomerates. The middle sandstone member, about $200 \mathrm{ft}$ thick, forms cliffs and terraced slopes. It consists of thick reddish-brown to maroon, fine- to medium-grained, massive, crossbedded, calcite-cemented sandstone in beds intercalated with thin grayish-red and greenish-gray silty shale beds, calcareous clay lenses, and thin limestone-pebble conglomerate beds. The middle member contains local abundances of organic material. The upper member is composed of about $180 \mathrm{ft}$ of interbedded grayish-red and greenish-gray shale, thick-bedded 
reddish-brown siltstone, and massive light-gray sandstone. The sandstone is fine to medium grained, and the beds are less than $10 \mathrm{ft}$ thick. The Chinle Formation was probably deposited in a complex stream-channel system with adjacent flood plains, lakes, and ponds.

A Middle Jurassic sandstone overlies the Chinle Formation. The name Entrada Sandstone is used in this report from Wanek (1962) and McLemore and Menzie (1983). Scott (1986) has used the name Exeter Sandstone, rather than Entrada, for these same rocks in the Springer area to the north. This eolian sandstone, about $80 \mathrm{ft}$ thick, forms prominent salmon-orange cliffs. The sandstone is massive, crossbedded, fine to medium grained, and well sorted.

The Entrada Sandstone is overlain by the Morrison Formation of Late Jurassic age. The Morrison Formation is about $350 \mathrm{ft}$ thick and is divided into three members: a lower red shale, a middle sandstone, and an upper green shale. The lower member consists of thick reddish-brown siltstone and variegated shale beds and thin to medium beds of pale-red to buff sandstone. The middle member is composed of massive, crossbedded buff to pale-orange sandstone interbedded with variegated calcareous shale beds and a few thick, buff, medium-grained, crosslaminated, lenticular sandstone beds. The upper member includes a few of these buff sandstone beds in a sequence dominated by green and variegated shales and mudstones with some organic debris. The Morrison Formation was deposited in stream-channel, flood-plain, and lacustrine environments.

The Mesa Rica sandstone, of Early Cretaceous age, unconformably overlies the Morrison Formation and caps many of the mesas in the Sabinoso Wilderness Study Area. The Mesa Rica Formation consists of buff to orange, massive, medium-grained, calcareous marine sandstone containing long, sweeping cross laminae. This sandstone is about $90 \mathrm{ft}$ thick, and weathering has produced a brown, varnished, pitted surface.

Paleozoic sedimentary rocks underlying the area may include the following formations, in descending order: the San Andres and Yeso Formations of Permian age and the Sangre de Cristo Formation of Permian and Pennsylvanian age. These formations are composed mostly of sandstone, siltstone, and shale but may contain some limestone and gypsum.

\section{Geophysics}

\section{Gravity Data}

An isostatic residual gravity map of a 15- by-30minute $(13.75 \times 35 \mathrm{mi}$ area) containing the wilderness study area (fig. 3) was compiled using 64 gravity stations. Thirteen of these stations provided data that were assembled and edited for regional gravity maps of New Mexico
(Cordell and others, 1982), and 51 stations were established for this study. A Bouguer reduction density of 2.4 $\mathrm{g} / \mathrm{cm}^{3}$ (grams per cubic centimeter) was used. Details of the Bouguer gravity reduction procedure are in Cordell and others (1982).

The isostatic residual gravity map (fig. 3) was made from the Bouguer anomaly data using an Airy isostaticcompensation model (Simpson and others, 1983). The map emphasizes the gravity effect of density variations in the upper crust (Simpson and others, 1986).

\section{Aeromagnetic Data}

An aeromagnetic map of a 15-by-30-minute area containing the wilderness study area is shown in figure 4. The aeromagnetic survey was flown in 1985 by EG\&G Geometrics under contract to the U.S. Geological Survey. The flight lines were east-west $0.5 \mathrm{mi}$ apart and $300 \mathrm{ft}$ above ground. The International Geomagnetic Reference Field was removed from the flight-line data by the contractor. The data were then interpolated onto a regular grid by a computer program (Webring, 1981) based on minimum curvature (Briggs, 1974).

\section{Interpretation of Gravity and Magnetic Data}

Both the gravity and magnetic maps (figs. 3, 4) are dominated by an elongate northwest-trending low which increases to the southeast. This magnetic and gravity low is probably due to a combination of structural relief on and lithologic heterogeneity of the Precambrian basement rocks.

The similarity between the aeromagnetic and gravity lows is best demonstrated by comparing the gravity map (fig. 3) to a pseudogravity map (fig. 5). The pseudogravity map was computed from the aeromagnetic data using the assumption that density is proportional to magnetization. The similarity between the gravity and pseudogravity maps, obvious especially where the gravity data are well constrained, supports the proportionality assumption and strongly suggests that the sources causing the major gravity features are the same as those producing the major aeromagnetic features. This relationship is unusual compared to other areas.

The gravity and aeromagnetic sources in common can be further confined to basement features because (1) significant density heterogeneities in the sedimentary sequence overlying the Precambrian in this area are unlikely, and (2) the sedimentary sequence is effectively nonmagnetic except for surface flows of basaltic lava in the valley of the Canadian River. This veneer of basalt is expressed as short-wavelength perturbations in the magnetic field to the north and east of the wilderness study area but does not produce a major aeromagnetic feature. 


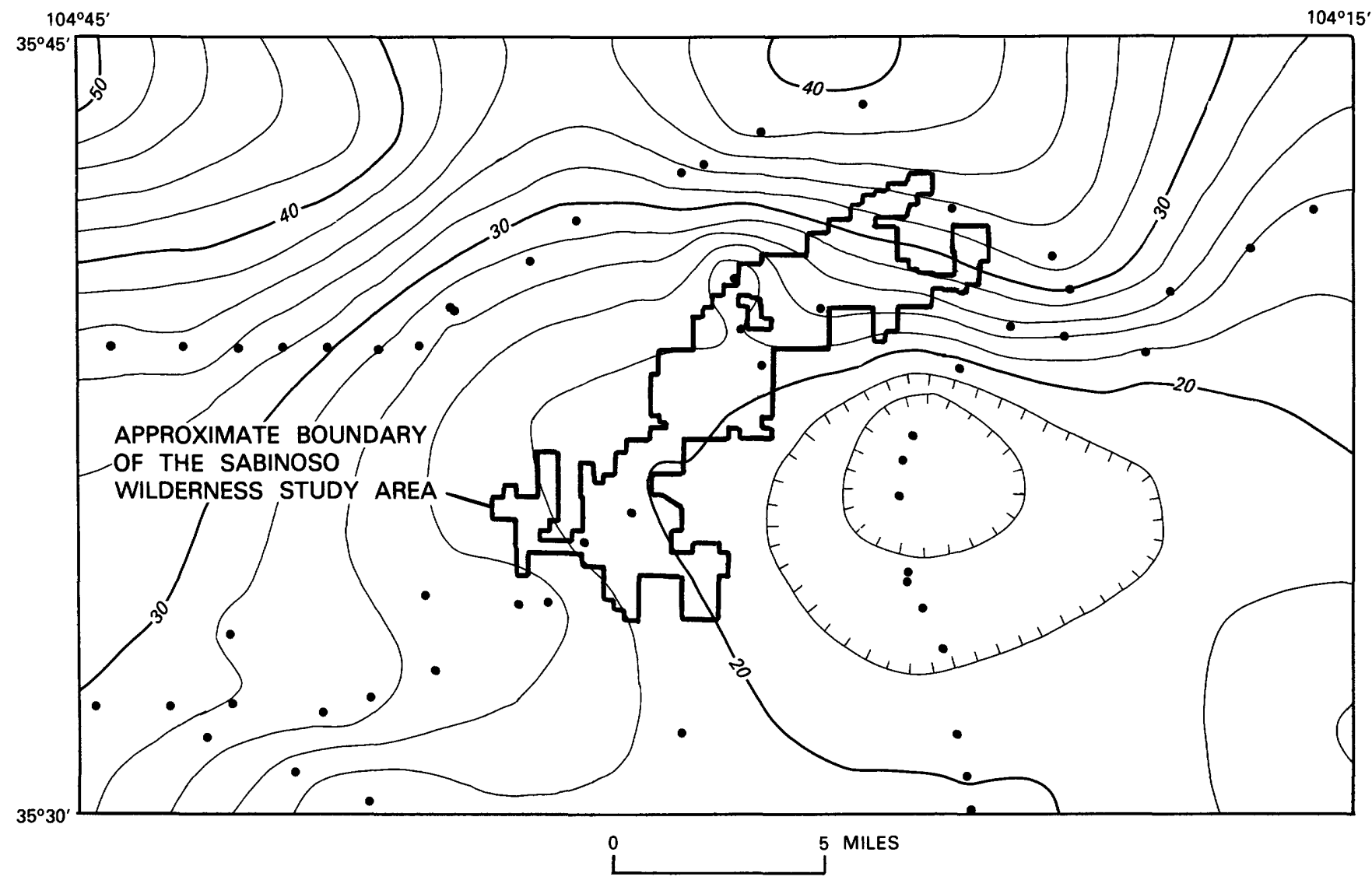

EXPLANATION

- 30 Gravity contour-Contour interval 2 milligals. Hachures show closed areas of lower gravity values

- Gravity station-Mostly along roads and trails

Figure 3. Isostatic residual gravity map of the Sabinoso Wilderness Study Area and vicinity, New Mexico. A reduction density of $2.4 \mathrm{~g} / \mathrm{cm}^{3}$ was used.

Two-dimensional profiles crossing the gravity and aeromagnetic lows, such as the one through the lowest and highest magnetic anomalies on the map (line $A-A^{\prime}$, fig. 4), were modeled using simplified geometries in conjunction with the gravity data and basement-depth constraints. These profiles show that the basement must be lithologically heterogeneous and that there may be a structural depression coinciding with the geophysical trough. Constraints on general basement depth were provided by a contour map of the Precambrian surface in northeastern New Mexico based on geophysical (gravity and magnetic), geological (surface outcrops), and drill-hole data (Andreasen and others, 1962). The predicted elevation of the Precambrian surface in this area is about $2,500 \mathrm{ft}$ above sea level.

Models that assumed that the basement rocks were homogeneous required unrealistically high magnetic inten- sities and (or) violated the constraints on basement depth. Models that assumed heterogeneous basement rocks and approximated the top of the Precambrian basement as a horizontal surface near $2,500 \mathrm{ft}$ above sea level gave more realistic density and magnetization ranges. The density contrasts in this model (assuming heterogenous basement rocks) range from $0.29 \mathrm{~g} / \mathrm{cm}^{3}$ under the deepest part of the gravity field to $0.49 \mathrm{~g} / \mathrm{cm}^{3}$ under the high to the northeast of the wilderness study area. This range of density contrasts, corresponding to rock densities of 2.69-2.89 $\mathrm{g} / \mathrm{cm}^{3}$, is somewhat higher than the range of $0.2-0.3$ $\mathrm{g} / \mathrm{cm}^{3}$ given by Andreasen and others (1962) as reasonable for northeastern New Mexico. However, the range of rock densities is consistent with average densities determined from drill-hole well samples (in a similar geologic environment) in Alberta, Canada (Garland and Burwash, 1959): $2.64 \mathrm{~g} / \mathrm{cm}^{3}$ for granitic (felsic) rocks, $2.91 \mathrm{~g} / \mathrm{cm}^{3}$ 


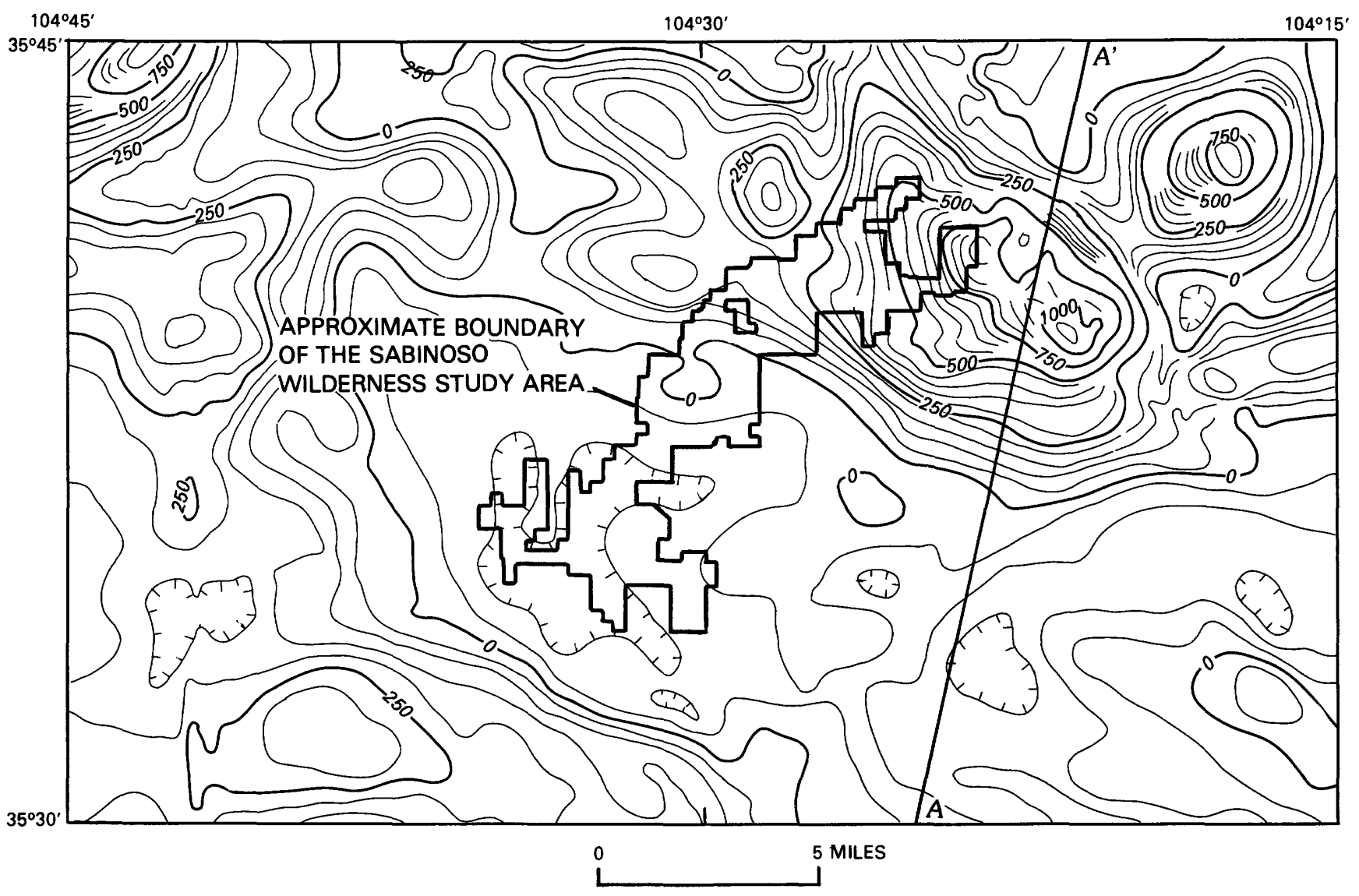

EXPLANATION

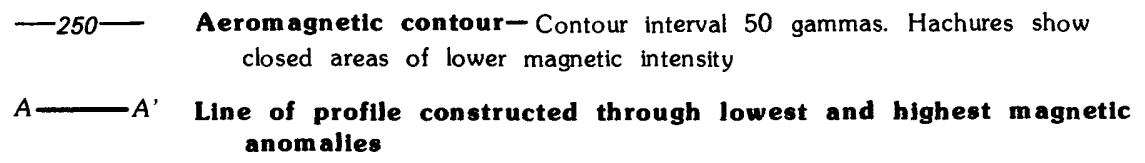

Figure 4. Aeromagnetic map of the Sabinoso Wilderness Study Area and vicinity, New Mexico.

for mafic rocks, and $2.70 \mathrm{~g} / \mathrm{cm}^{3}$ for other Precambrian rocks (mainly gneiss). Drill holes in the vicinity of the wilderness study area pentrated all three rock types in the Precambrian basement: metamorphic intermediatecomposition rocks, granite, and mafic igneous rocks.

The required magnetic intensities for this model vary proportionately with the rock densities and range from $0.0029 \mathrm{emu} / \mathrm{cm}^{3}$ (electromagnetic units per cubic centimeter) to $0.0064 \mathrm{emu} / \mathrm{cm}^{3}$. This range of intensities (corresponding roughly to a susceptibility range of $5 \times 10^{-3}$ to $12 \times 10^{-3}$ in the centimeter-gram-second system of units) is fairly high, to be expected from mafic igneous rocks. However, because of modeling limitations, the relative difference in intensity may be more significant than the actual values.

If the highly magnetic and dense areas modeled on either side of the geophysical trough are also areas of higher structural elevation, then the densities and intensities required for the model may be lessened somewhat. However, the amount of structural relief, if any, cannot be constrained by the available data.

In a regional geophysical study of the central Colorado Plateau (Case and Joesting, 1972), which, like the study area, has a thick sedimentary-rock cover over Precambrian basement rocks, the basement was found to be extremely heterogeneous. In that study, patterns of steepened magnetic and gravity gradients were interpreted to represent lithologic contacts, and gradients which were "crudely oval or circular" were interpreted as intrusive contacts. Thus, the central geophysical trough may represent a zone of less dense and less magnetic (felsic?) material that intruded relatively more dense and more magnetic (mafic?) rock. One drill hole within the area of the geophysical trough (fig. 4) penetrated $33 \mathrm{ft}$ of gabbro(?) 


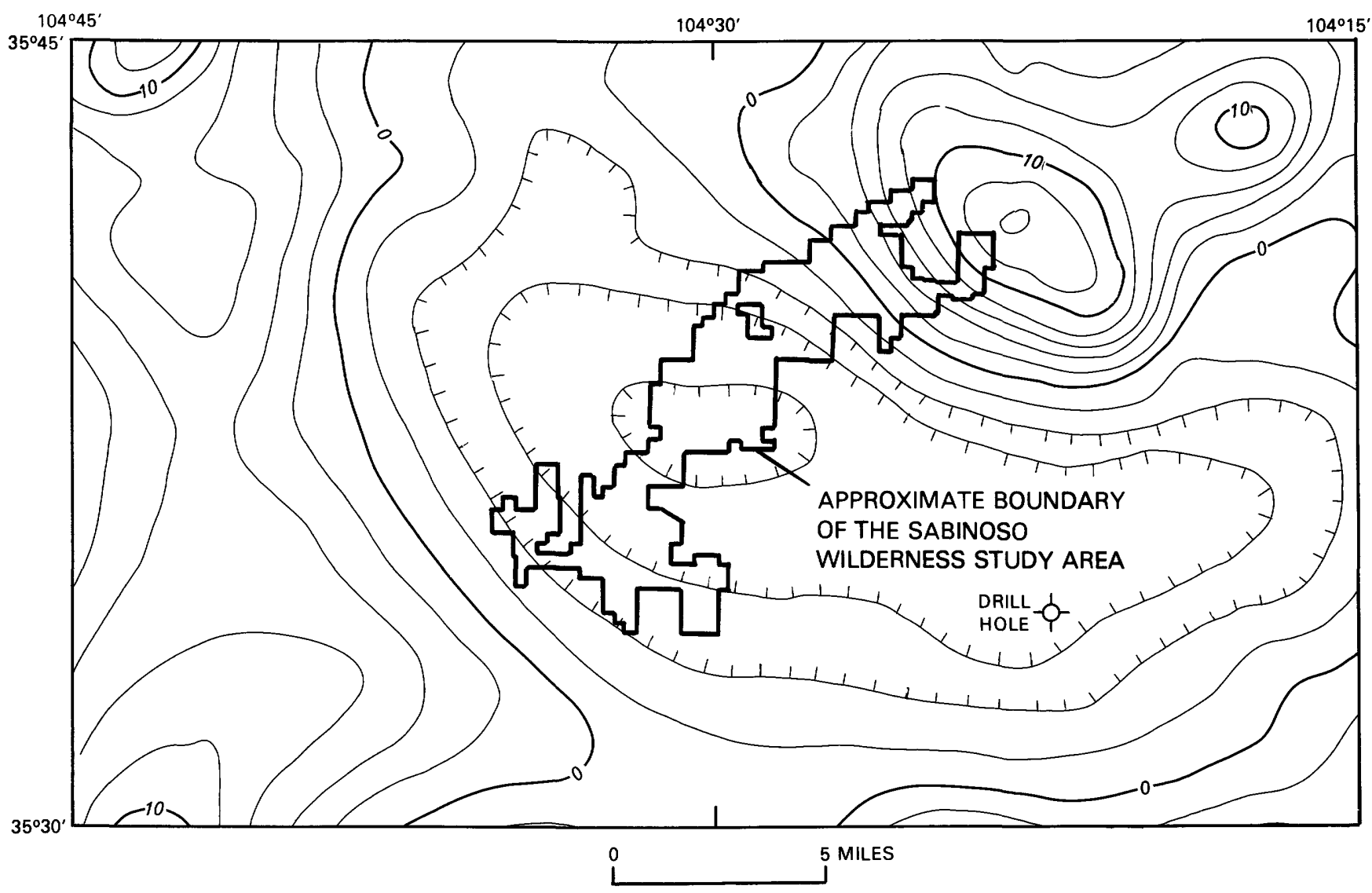

Figure 5. Pseudogravity map of the Sabinoso Wilderness Study Area and vicinity, New Mexico. This map was constructed from the aeromagnetic map (fig. 4) and represents the gravity field which would result if source-rock magnetization and rock density were proportional. The contour interval is 2 pseudomilligals. Hachures show closed areas of lower pseudogravity values.

and $14 \mathrm{ft}$ of coarse-grained granite, rock types that lend some support to this hypothesis of less dense rocks within more dense rocks.

\section{Radiometric Data}

Aerial gamma-ray spectroscopy is a technique that estimates the near-surface $(0-50 \mathrm{~cm}$ (centimeter) depth) concentrations of potassium ( $\mathrm{K}$, in percent), equivalent uranium (eU, in parts per million), and equivalent thorium (eTh, in parts per million). Because the uranium and thorium measurements utilize radioactive daughter nuclei that are chemically distinct from the parent nuclei, the uranium and thorium data are described as equivalent concentrations. These data on $\mathrm{K}, \mathrm{eU}$, and $\mathrm{eTh}$ provide a partial geochemical representation of the near-surface materials. For a typical aerial survey, each measurement reflects average concentrations for a surface area of about 60,000 square meters to an average depth of about 30 cm (J. S. Duval, written commun., 1986).
From 1975 to 1983, the U.S. Department of Energy contracted for aerial gamma-ray surveys that covered almost all of the conterminous United States and much of Alaska. The flight-line spacings of these surveys vary from $1 \mathrm{mi}$ (rare) to $10 \mathrm{mi}$ and are, in general, only suitable for producing regional-scale maps.

As part of a state mapping project, the data for New Mexico were compiled and processed to produce a series of 1:1,000,000-scale maps. These maps were examined to estimate the $\mathrm{K}, \mathrm{eU}$, and $\mathrm{eTh}$ concentrations for the wilderness study area, and the occurrence or absence of anomalous radioelement concentrations were noted. The definition of an anomaly is that the element concentration as well as its ratios to the other two elements all be high values in the context of the map area. The Sabinoso Wilderness Study Area has overall low radioactivity with concentrations of $0.9-1.3$ percent $\mathrm{K}, 1.5-2.5 \mathrm{ppm} \mathrm{eU}$, and 6-8.5 ppm eTh. No anomalies are within or near the study area (J. S. Duval, written commun., 1986). 


\section{Mineral and Energy Resources}

The mineral resource potential for the Sabinoso Wilderness Study Area was assessed by comparing geological and geophysical characteristics of the study area with those of nearby mineralized areas and with resourcedeposit models. Geological and geophysical features of the study area suggest that three possible types of mineral resources are present: (1) uranium in the Chinle Formation, (2) uranium in the Morrison Formation, and (3) oil and gas in the underlying Permian and Pennsylvanian rocks.

Most uranium deposits near the study area are associated with carbonaceous organic material, calcareous clay lenses, and limestone-pebble conglomerate lenses in the middle member of the Triassic Chinle Formation. Those deposits are small, low grade (less than 0.10 percent $\mathrm{U}_{3} \mathrm{O}_{8}$ ), and discontinuous. These characteristics may be, in part, due to the lack of abundant organic material and the small-scale geometry of alluvial facies in the Chinle Formation in the Sabinoso area. Still, ample evidence shows that the mineralizing process occurred in the study area. Therefore, the wilderness study area is assigned a moderate mineral resource potential for uranium in the Chinle Formation, with certainty level B.

Some uranium deposits have been identified in the upper member of the Morrison Formation in northern San Miguel and southern Haring Counties, New Mexico (McLemore and North, 1985). These deposits contain either small, low-grade accumulations of uranium in sandstone and marl or uraniferous fossil logs and fossil bones. No deposits of this type are known in the wilderness study area, and the Morrison Formation lacks the abundant organic material associated with it in the larger uranium districts of the Colorado Plateau, particularly the Grants district. The Sabinoso Wilderness Study Area is assigned a low mineral resource potential for uranium in the Morrison Formation, with certainty level B.

No drilling for oil and gas has been reported within the Sabinoso Wilderness Study Area; however, many wells have been drilled in the region. Characteristics favorable for the presence of oil and gas in the region include: (1) The area is underlain by a sequence of Mesozoic and upper Paleozoic sedimentary rocks as thick as $3,500 \mathrm{ft}$. Some of these formations produce oil and gas elsewhere. (2) Geophysical maps are dominated by an elongate northwest-trending gravity and magnetic low. Fluids often accumulate along the margins of structurally high areas, where reservoir rocks pinch out against the positive area (Wanek, 1962). The presence of a major structural depression in the area could not be determined from available data.

Ryder (1983) rated the hydrocarbon potential of the study area low because data from nearby drill holes indicate that the sedimentary rocks under the study area are not suitable source or reservoir rocks in this area. The nearest drill holes having recorded hydrocarbon shows are 7 and 12 mi east of the study area, and many other nearby drill holes have shown no indication of oil and gas. Therefore, the Sabinoso Wilderness Study Area is assigned a low potential for oil and gas resources; the certainty level is $B$.

A favorable geologic environment for the presence of metallic mineral resources is lacking in the study area. In addition, geochemical evidence (Almquist, 1986) does not indicate abnormally high concentrations of metals for this environment. Therefore, the study area is assigned low mineral resource potential for all metals other than uranium; certainty level is $\mathrm{C}$.

\section{REFERENCES CITED}

Allison, J. W., 1956, Supplement to preliminary reconnaissance report-San Carlos Mining Co.: U.S. Atomic Energy Commission Report ASO-138, 2 p. Available from National Technical Information Service, U.S. Department of Commerce, 5285 Port Royal Road, Springfield, VA 22161.

Almquist, C. L., 1986, Mineral investigation of the Sabinoso Wilderness Study Area (NM-010-055), San Miguel County, New Mexico: U.S. Bureau of Mines Open-File Report MLA 28-86, $11 \mathrm{p}$.

Andreasen, G. E., Kane, M. F., and Zietz, Isidore, 1962, Aeromagnetic and gravity studies of the Precambrian in northeastern New Mexico: Geophysics, v. 27, no. 3, p. 343-358.

Briggs, I. C., 1974, Machine contouring using minimum curvature: Geophysics, v. 39, no. 1, p. 39-48.

Case, J. E., and Joesting, H. R., 1972, Regional geophysical investigations in the Central Colorado Plateau: U.S. Geological Survey Professional Paper 736, 31 p.

Cordell, Lindrith, Keller, G. R., and Hildenbrand, T. G., 1982, Bouguer gravity map of the Rio Grande Rift, Colorado, New Mexico, and Texas: U.S. Geological Survey Geophysical Investigations Map GP-949, scale 1:1,000,000.

Duval, J. S., 1983, Composite color images of aerial gamma-ray spectrometric data: Geophysics, v. 48, no. 6, p. 722-735.

Finch, W. I., 1972, Uranium in eastern New Mexico, in Eastcentral New Mexico: New Mexico Geological Society, 23rd Annual Field Conference, Guidebook, p. 171-175.

Garland, G. D., and Burwash, R. A., 1959, Geophysical and petrological study of Precambrian of central Alberta, Canada: American Association of Petroleum Geologists Bulletin, v. 43 , no. 4 , p. $790-806$.

Goudarzi, G.H., compiler, 1984, Guide to preparation of mineral survey reports on public lands: U.S. Geological Survey Open-File Report 84-787, 42 p.

McLemore, V. T., and Menzie, D., 1983, Geology and uranium potential of Sabinoso district, San Miguel County, New Mexico: New Mexico Geology, v. 5, no. 2, p. 35-40.

McLemore, V.T., and North, R.M., 1985, Copper and uranium mineralization in east-central New Mexico, in Lucas, S.G., ed., Santa Rosa-Tucumcari region: New Mexico Geological Society, 36th Annual Field Conference, Guidebook, p. 289300 . 
Ryder, R. T., 1983, Petroleum potential of wilderness lands in New Mexico, in Petroleum potential of wilderness land in the western United States: U.S. Geological Survey Circular 902 A-P, p I1-I33.

Scott, G.R., 1986, Geologic and structure contour map of the Springer $30^{\prime} \times 60^{\prime}$ quadrangle, Colfax, Harding, Mora, and Union Counties, New Mexico: U.S. Geological Survey Miscellaneous Investigations Series Map I-1705.

Simpson, R. W., Jachens, R. C., and Blakely, R. J., 1983, AIRYROOT-A Fortran program for calculating the gravitational attraction of an Airy isostatic root out to $166.7 \mathrm{~km}$ : U.S. Geological Survey Open-File Report 83-883, 66 p.

Simpson, R. W., Jachens, R. C., Blakely, R. J., and Saltus, R. W., 1986, A new isostatic residual gravity map for the conterminous United States with a discussion of the significance of isostatic anomalies: Journal of Geophysical Research, v. 91, no. B8, p. 8348-8372.

U.S. Atomic Energy Commission, 1953-56, Preliminary reconnaissance reports and supplements, 1953-1956: U.S. Atomic Energy Commission, Grand Junction, Colo., unpublished reports available from National Technical Information Service, U.S. Department of Commerce, 5285 Port Royal Rd., Springfield, VA 22161.
1966, U.S. Atomic Energy Commission airborne radiometric reconnaissance in Arizona, California, Nevada, and New Mexico, 1953-1956: U.S. Atomic Energy Commission Report RME-147, p. 37; available from National Technical Information Service, U.S. Department of Commerce, 5285 Port Royal Rd., Springfield, VA 22161.

U.S. Bureau of Mines and U.S. Geological Survey, 1980, Principles of a resource/reserve classification for minerals: U.S. Geological Survey Circular 831, 5 p.

U.S. Department of the Interior, Bureau of Land Management, 1985, New Mexico Statewide Wilderness Study, volume 2; Appendices, Wilderness Analysis Reports: unpublished report available from New Mexico State Office, U.S. Bureau of Land Management, P.O. Box 1449, Santa Fe, N. Mex. 87501.

Wanek, A. A., 1962, Reconnaissance geologic map of parts of Harding, San Miguel, and Mora Counties, New Mexico: U.S. Geological Survey Oil and Gas Investigations Map OM-208, scale 1:96,000.

Webring, M. W., 1981, MINC, a gridding program based on minimum curvature: U.S. Geological Survey Open-File Report 81-1224. 
APPENDIX 


\section{DEFINITION OF LEVELS OF MINERAL RESOURCE POTENTIAL AND CERTAINTY OF ASSESSMENT}

\section{Definitions of Mineral Resource Potential}

LOW mineral resource potential is assigned to areas where geologic, geochemical, and geophysical characteristics define a geologic environment in which the existence of resources is unlikely. This broad category embraces areas with dispersed but insignificantly mineralized rock as well as areas with few or no indications of having been mineralized.

MODERATE mineral resource potential is assigned to areas where geologic, geochemical, and geophysical characteristics indicate a geologic environment favorable for resource occurrence, where interpretations of data indicate a reasonable likelihood of resource accumulation, and (or) where an application of mineral-deposit models indicates favorable ground for the specified type(s) of deposits.

HIGH mineral resource potential is assigned to areas where geologic, geochemical, and geophysical characteristics indicate a geologic environment favorable for resource occurrence, where interpretations of data indicate a high degree of likelihood for resource accumulation, where data support mineral-deposit models indicating presence of resources, and where evidence indicates that mineral concentration has taken place. Assignment of high resource potential to an area requires some positive knowledge that mineral-forming processes have been active in at least part of the area.

UNKNOWN mineral resource potential is assigned to areas where information is inadequate to assign low, moderate, or high levels of resource potential.

NO mineral resource potential is a category reserved for a specific type of resource in a well-defined area.

Levels of Certainty

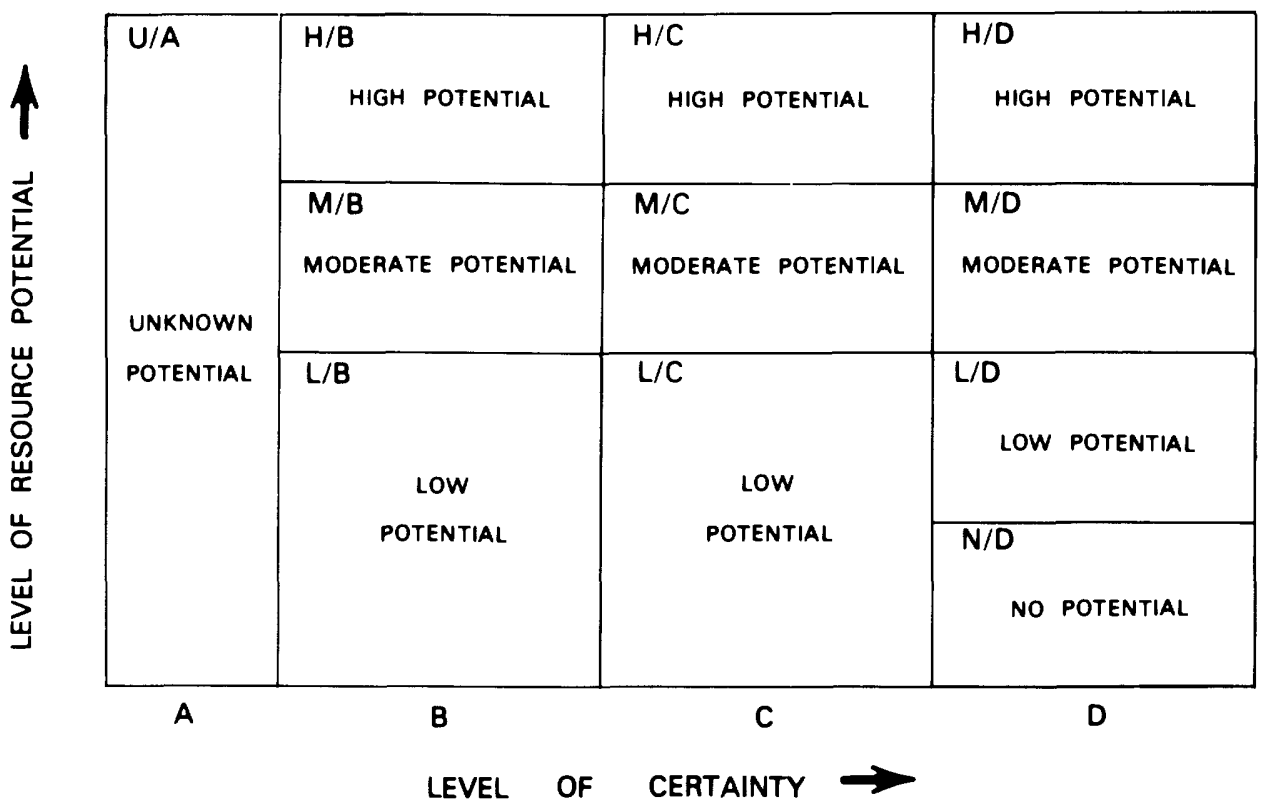

A. Available information is not adequate for determination of the level of mineral resource potential.

B. Available information suggests the level of mineral resource potential.

C. Available information gives a good indication of the level of mineral resource potential.

D. Available information clearly defines the level of mineral resource potential.

\section{Abstracted with minor modifications from:}

Taylor, R. B., and Steven, T. A., 1983, Definition of mineral resource potential: Economic Geology, v. 78 , no. 6 , p. $1268-1270$.

Taylor, R. B., Stoneman, R. J., and Marsh, S. P., 1984, An assessment of the mineral resource potential of the San Isabel National Forest, south-central Colorado: U.S. Geological Survey Bulletin 1638, p. $40-42$.

Goudarzi, G. H., compiler, 1984, Guide to preparation of mineral survey reports on public lands: U.S. Geological Survey Open-File Report 84-0787, p. 7, 8. 


\begin{tabular}{|c|c|c|c|c|c|}
\hline & \multicolumn{5}{|c|}{ RESOURCE / RESERVE CLASSIFICATION } \\
\hline & \multicolumn{3}{|c|}{ IDENTIFIED RESOURCES } & \multirow{2}{*}{\multicolumn{2}{|c|}{$\frac{\text { UNDISCOVERED RESOURCES }}{\text { Probability Range }}$}} \\
\hline & \multicolumn{2}{|c|}{ Demonstrated } & \multirow{2}{*}{ Inferred } & & \\
\hline & Measured & Indicated & & Hypothetical & Speculative \\
\hline ECONOMIC & & & Inferred Reserves & & \\
\hline $\begin{array}{l}\text { MARGINALLY } \\
\text { ECONOMIC }\end{array}$ & Margina & eserves & $\begin{array}{c}\text { Inferred } \\
\text { Marginal Reserves }\end{array}$ & & \\
\hline $\begin{array}{c}\text { SUB- } \\
\text { ECONOMIC }\end{array}$ & $\begin{array}{r}\text { Dem } \\
\text { Subeconon }\end{array}$ & $\begin{array}{l}\text { Resources } \\
\text { Retrated }\end{array}$ & $\begin{array}{l}\text { Inferred } \\
\text { Subeconomic } \\
\text { Resources }\end{array}$ & & \\
\hline
\end{tabular}

Major elements of mineral resource classification, excluding reserve base and inferred reserve base. Modified from U. S. Bureau of Mines and U. S. Geological Survey, 1980, Principles of a resource/reserve classification for minerals: U. S. Geological Survey Circular 831, p. 5. 
GEOLOGIC TIME CHART

Terms and boundary ages used by the U.S. Geological Survey, 1986

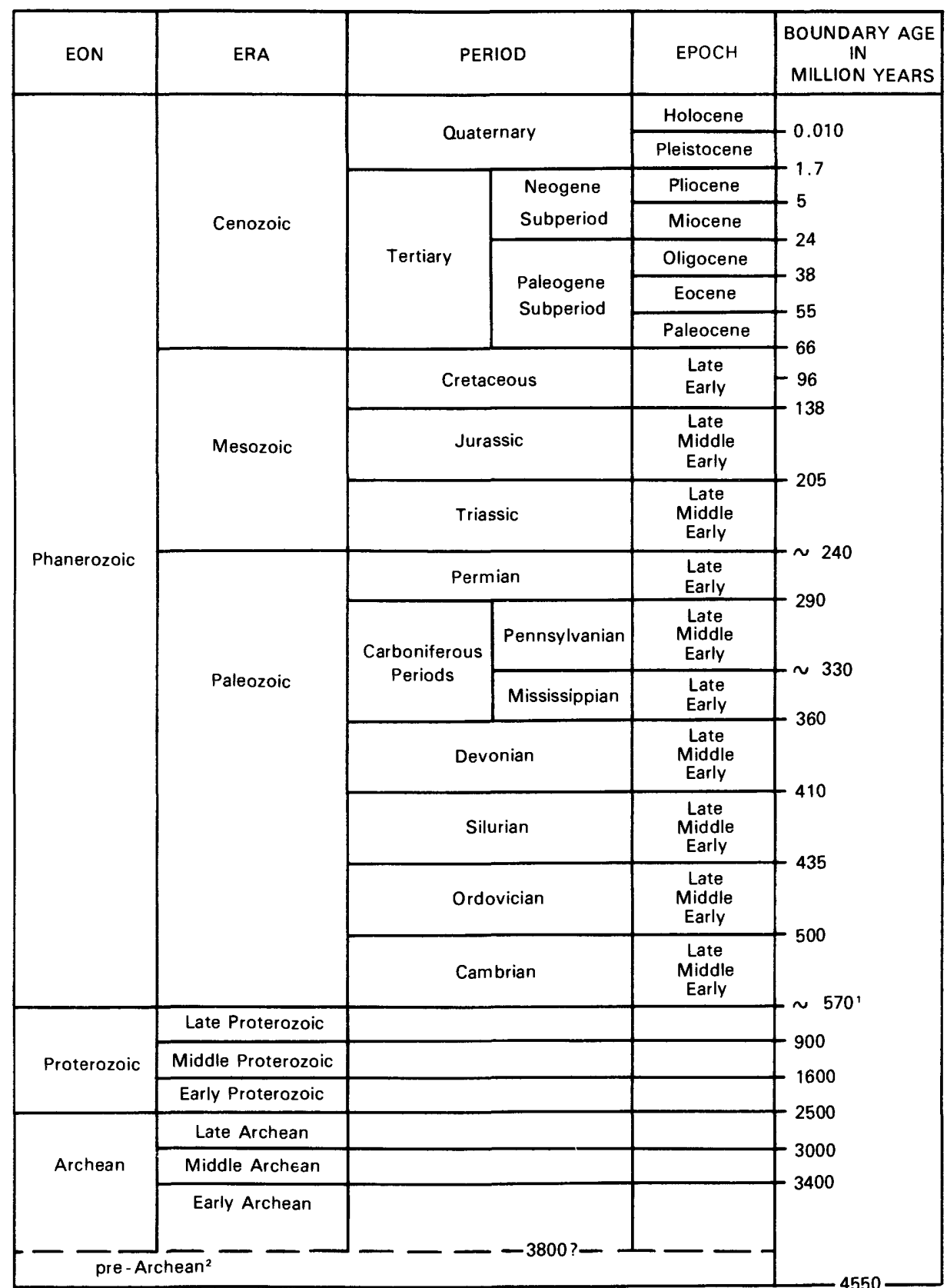

' Rocks older than $570 \mathrm{~m}$.y. also called Precambrian, a time term without specific rank.

2 Informal time term without specific rank. 


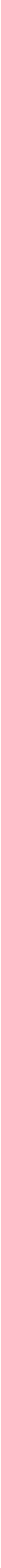




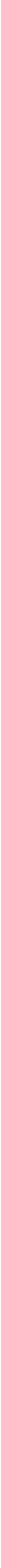

